Guilherme Cepellos Monticelli

\begin{abstract}
ANÁLISE DINÂMICA NÃO LINEAR BIDIMENSIONAL LOCAL DE RISERS EM CATENÁRIA CONSIDERANDO CONTATO UNILATERAL VISCOELÁSTICO
\end{abstract}



Este exemplar foi revisado e alterado em relação à versão original, sob responsabilidade única do autor e com a anuência de seu orientador.

São Paulo, de ..de 20

Assinatura do autor

Assinatura do orientador

FICHA CATALOGRÁFICA

Monticelli, Guilherme Cepellos

Análise dinâmica não linear bidimensional local de risers em catenária considerando contato unilateral viscoelástico / G.C. Monticelli. -- ed.rev. -- São Paulo, 2013.

90 p.

Dissertação (Mestrado) - Escola Politécnica da Universidade de São Paulo. Departamento de Engenharia de Estruturas e Geotécnica.

1. Dinâmica das estruturas 2. Método de Galerkin 3. Estrutura offshore 4. Modelagem de ordem reduzida I. Universidade de São Paulo. Escola Politécnica. Departamento de Engenharia de Estruturas e Geotécnica II. t. 
Guilherme Cepellos Monticelli

\section{ANÁLISE DINÂMICA NÃO LINEAR BIDIMENSIONAL LOCAL DE RISERS EM CATENÁRIA CONSIDERANDO CONTATO UNILATERAL VISCOELÁSTICO}

Dissertação apresentada à Escola

Politécnica da Universidade de São

Paulo para obtenção do título de

Mestre em Engenharia

Área de concentração:

Engenharia de Estruturas

Orientador:

Prof. Dr. Carlos Eduardo Nigro Mazzilli

São Paulo 
Resumo

O estudo da dinâmica estrutural de risers oceânicos apresenta instigantes desafios aos pesquisadores da área da engenharia de estruturas, uma vez que os meios tradicionais de análises dinâmicas lineares nem sempre se ajustam às suas complexas particularidades. No atual estágio do desenvolvimento científico da área de engenharia de estruturas, a aplicação de técnicas de análise dinâmica não linear, dentro de determinadas hipóteses, mostra-se como uma das alternativas possíveis e viáveis à tradicional análise dinâmica linear. Com vistas a uma nova abordagem do problema, o presente trabalho adota uma metodologia de análise não linear dinâmica de risers oceânicos em configuração de lançamento de catenária, conjugada a uma técnica de processamento de Modelos de Ordem Reduzida para o estudo dos fenômenos dinâmicos manifestados por risers. Trata-se de um método de modelagem local, restrito à região de contato unilateral do riser com o solo, considerado este último um meio viscoelástico. Os resultados da aplicação desta metodologia são demonstrados nos estudos de caso apresentados com comparações com modelos numéricos (Método dos Elementos Finitos) e modelos físi$\cos$. 


\begin{abstract}
The dynamic study of offshore risers still demands large efforts from structural engineering researchers, since these systems may behave in a way that is not well modeled and understood using simply linear dynamic theories. Nevertheless, the current development stage of non linear dynamic theories gives hope that their use for the analyses of such systems can be of great value, even though, this must be carefully done specially by the analyst. The present work refers to a non linear dynamic methodology application to offshore risers, particularly steel catenary risers, by a technique known as "reduced-order modeling", in the study of dynamic phenomena that these structures may present. The model is local, which means that it represents the touch-down zone of the riser-soil system. The soil modeling was presumed to be viscoelastic. The results obtained in case studies are compared with those from numerical (Finite Element Method) and small scale physical models.
\end{abstract}

